\title{
Hauntological Pedagogies: Confronting the Ghosts of Whiteness and Moving towards Racial and Spiritual Justice
}

\author{
M. Nathan Tanner $(\mathbb{D}$
}

check for updates

Citation: Tanner, M. Nathan. 2022. Hauntological Pedagogies: Confronting the Ghosts of Whiteness and Moving towards Racial and Spiritual Justice. Religions 13: 83 https://doi.org/10.3390/ rel13010083

Academic Editor: Melanie C. Brooks

Received: 23 November 2021

Accepted: 12 January 2022

Published: 17 January 2022

Publisher's Note: MDPI stays neutral with regard to jurisdictional claims in published maps and institutional affiliations.

Copyright: (C) 2022 by the author. Licensee MDPI, Basel, Switzerland. This article is an open access article distributed under the terms and conditions of the Creative Commons Attribution (CC BY) license (https:// creativecommons.org/licenses/by/ $4.0 /)$.
Department of Education Policy, Organization \& Leadership, University of Illinois, Champaign, IL 61820, USA; marknt2@illinois.edu

\begin{abstract}
The purpose of this conceptual article is to bring critical theoretical frameworks and discourses used in educational research on leadership, pedagogy, and policy into conversation with literature on hauntology. Furthermore, this work aims to pursue avenues for theorizing and developing notions of hauntological pedagogies by evoking the language and imagery of ghosts to confront the political, social, and spiritual problems in U.S. schooling contexts that stem from whiteness. This article is grounded in the critical discourses of antiracism, BlackCrit, critical pedagogy, critical race theory, critical whiteness studies, decolonial studies, and TribalCrit. By juxtaposing historical and contemporary case studies in U.S. schooling, this study demonstrates that whiteness, apart from constituting a socially constructed set of power relations, takes on religious or spiritual qualities. Critical educational researchers and practitioners will benefit from engaging with this work as it can help them conceive of and strive for more epistemologically, racially, and spiritually just schooling environments.
\end{abstract}

Keywords: hauntology; hauntological pedagogies; whiteness; epistemology; critical pedagogy; history of education; philosophy of education; educational leadership; racial justice; spiritual justice

\section{Introduction}

Since antiquity, peoples from vastly different parts of the globe have produced accounts of ghosts; apparitions or specters that exist somewhere in between time and space (Clarke 2012). Tales of the spectral from early China, for example, are meant to remind members of a cultural group to secure relationships between living kin and their place in society, thereby proliferating in-group traditions essential to cultural education and survival (Puett 2014). However, most "Western" - or white, Euro-American Christian-accounts and hermeneutics often describe the role that ghosts play as one of "haunting" the living or distorting reality (Davis 2005; Hartman 2010; Leonardo 2009, p. 185). In much of the literary canon that falls under the umbrella of the "Western" tradition, ghosts are frequently depicted as "disturbance[s]" with "elusive identities," phantasms that compete for varying "epistemological and ethical positions" (Davis 2005, p. 379).

As an academic endeavor in international scholarly literature, attending to ghosts and their haunting ontologies has been traced to the work of French philosopher Derrida ([1993] 1994) who coined the term hauntology to describe the inquiry of "that which is neither present nor absent, neither dead nor alive" (Davis 2005). This article takes methodological direction for engaging in hauntological inquiry from models put forth by Zembylas (2013) for history educators. According to Zembylas (2013, p. 69), hauntology presupposes "an ongoing conversation with the ghost" as a way to "trouble the hegemonic status of representational modes of knowledge" and their associated practices. Since Derrida's groundbreaking (if not, controversial) scholarly contribution, literary critics (Hartman 2010), pedagogues (Butler and Athanasiou 2013; Leonardo 2016; Morrill et al. 2016), philosophers (Zembylas 2013), and theologians (Caputo 2016; Caputo 2020) have contributed to an understanding of hauntology. Through their work, numerous scholars have engaged in a 
dialectic attempting to theorize and essentialize the "ghostly agents" whose "mission[s], provenance, shape, sex, or even longevity" (Hartman 2010, p. 5) are in constant contestation.

While education literature has to a degree acknowledged and contributed to the discourse on hauntology (Morrill et al. 2016; Yoon 2019a, 2019b; Zembylas 2013), many more contributions by educators, pedagogues, and theorists to this literature are needed. Critical discourses like antiracism (Diem and Welton 2021; Gillborn 2004), critical race theory (Bell 1996; Dixson et al. 2017; Lynn and Dixson 2013), critical whiteness studies in education (Gillborn 2005; Howard 2004; Leonardo 2009), BlackCrit (Dumas and Ross 2016), TribalCrit (Brayboy 2005), and decolonial studies (Grande 2015; Smith 2021; Tuck and Yang 2012) provide the most auspicious entry for educational theorists and practitioners into the hauntology dialectic. This can be attributed to these critical discourses' emphasis on understanding oppression as an historically constructed enterprise that is coterminous with white Christian colonization, but that is ongoing and ever changing (Bell 1992; Leonardo 2016; Wynter 2003). To one degree or another, these critical discourses also engage with the liminal space between past and present. As shall be discussed more in-depth hereafter, hauntological pedagogies rely heavily on the collapsing of the space time continuum to engage in reflexive dialogue with the ghastly memories of disparate ethnic, racial, and spiritual communities, oppressed or not.

Noteworthy gains in educational theory and praxis can come from centering ghost stories like those mentioned above, while attending specifically to the racial and spiritual intersections of their subsistence in U.S. educational and schooling contexts (Du Bois [1920] 1999). I make a distinction between education and schooling contexts intentionally here. Numerous scholars have emphasized the ways that schools function as sites of "Western" coloniality, designed historically in the U.S. to deliberately assimilate or subordinate children and youth to socio-politically dominant epistemologies and ontologies (Adams 1995; Anderson 1988; Dumas 2016; Lomawaima 1994; Tamura 1994; Sánchez 1993). While this has not always been the case, as exemplified by Caswell County Training School in North Carolina (Siddle Walker 2000), the Rough Rock demonstration school (McCarty 2002), the Freedom Schools (Hale 2016), or the Survival Schools (Davis 2013), these are cases of historical exception rather than the general rule. On the other hand, education, can and indeed has functioned as a trans-spatial liberatory praxis for communities, groups, and nations before and since European colonization (Alridge et al. 2021; Estes 2020). In effect, both schooling and education contexts in what now comprises the U.S. have been and continue to be the sites of divergent ghostly hauntings. Schools have most frequently been the locations of ethereal disturbance to children and youth's identities a-lá-“'Western"-colonial tradition. Conversely, community-centered sites of education-which include places of spiritual ceremony and collective rejuvenation-are more akin to the spectral traditions evidenced in places like China (Eastman [1911] 1980, pp. 53-84; Garcia et al. 2020; Madyun and Witherspoon 2010). In effect, those spaces that engage in various forms of hauntological pedagogy.

In her article titled, Whiteness as Property, an essential critical race theory treatise cited regularly by critical researchers of educational leadership, pedagogy, and policy (LadsonBillings and Tate 1995; Dixson et al. 2017; Dumas and Ross 2016), Cheryl Harris says the following:

[Whiteness] is a ghost that has haunted the political and legal domains in which claims for justice have been inadequately addressed for far too long. Only rarely declaring its presence, it has warped efforts to remediate racial exploitation. It has blinded society to the systems of domination that work against so many by retaining an unvarying focus on vestiges of systemic racialized privilege that subordinates those perceived as aparticularized few-the "others". (Harris 1993, p. 1791)

In this passage, Harris, a critical race legal theorist, invokes hauntology (albeit without formal connection to the academic literature base that was only then emerging) and applies it to the concept and legal framework of whiteness. Rather than applying the language of haunting metaphorically, she essentializes its material reality as it has existed in political 
and legal spheres. This concept of whiteness as something more than a skin color, but as a globally systematized framework of socioeconomic and political power relations, finds its hermeneutical origins in Du Bois's ([1920] 1999) scholarship. Since Du Bois first attended to the critical study of whiteness, it has always been discussed in quasi-spiritual ways like those Euro-American ghost stories of the pre-modern era (Clarke 2012; Leonardo 2002; Lipsitz 1998; Mills 1997; Roediger 1991). Du Bois ([1920] 1999, p. 464), for example, famously wrote that whiteness was "rather [like] a great religion," with the objective of enslaving the globe for its own horrific gain.

Like the haunting of ghosts in the Euro-American Christian tradition, the purpose of whiteness is to displace those its benefactors perceive as "other" (Leonardo 2002; Morrill et al. 2016). It aims to deprive the other of protection and safety, to subordinate and terrorize them, and to secure material privileges for themselves without fully revealing their "codes" or innerworkings (Harris 1993; Hooks 1997, p. 169; Leonardo 2002, p. 31). The ghosts of whiteness torment those they oppress, despite their illusory nature. Like the ghosts of the European Christian past and present, neither here nor there, whiteness's modern "socio-spatial epistemology" makes it so that those believing themselves to be culturally, economically, and politically superior are "unable to understand the world they themselves have made" (Leonardo 2002, p. 40; Mills 1997, p. 18).

Ghosts of the white Euro-American Christian tradition are claimed to possess humankind and shapeshift in varying contexts; whiteness materializes similarly (Bell 1997; Davis 2005; Hartman 2010). Whiteness is, as Leonardo (2016) described, "best understood as a multiplicity". In effect, there are seemingly endless variations of identities and policies competing to institutionalize and norm white Christian power to disenfranchise and silence people of color (Hartman 2004; Jones 2021; Leonardo 2016). A poltergeist of modern humans' own making, whiteness as a system of power relations, materializes, possesses, and transforms in the spaces associated with the schooling of Black and Indigenous children and youth in the U.S. (Du Bois [1920] 1999). By scrutinizing the ghosts of whiteness from "various angles" (Leonardo 2016, p. 8), education scholars and practitioners can develop the tools to challenge and disrupt the problems of racism and spiritual injustice.

The purpose of this conceptual article is to bring critical theoretical frameworks and discourses into conversation with hauntology. Furthermore, this work aims to pursue avenues for theorizing and developing notions of hauntological pedagogies to confront the political, social, and spiritual problems in U.S. schooling contexts that stem from whiteness. Zembylas (2013, p. 86) has opined that effective hauntological pedagogies might consider engaging students in "spectral encounters" where "epistemological, political, or legal narratives [are] interrogate[d]". As shall be demonstrated hereafter, hauntological pedagogies already form an important part of Black and Indigenous critical pedagogies and the collective struggle against whiteness. From the vantage point of a series of historical episodes of U.S. education and schooling, additional witnesses (Lynn and Dixson 2013) to the horrifying "herrenvolk ethic" (Leonardo 2016, p. 7; Mills 1997) of whiteness are provided in this essay. Additionally, the epistemologies and spiritualities of Black and Indigenous peoples are highlighted to intentionally position them against the deliberate historical "silencing" of these communities' cultural wealth (Trouillot 1995; Yosso 2005).

Including both Black ${ }^{1}$ and Indigenous histories in this narrative is instructive, and it also constitutes an important relational approach to addressing the racial and spiritual injustices that empower whiteness. First, Black, and Indigenous peoples are not mutually exclusive relational categories (Kelley 2017). Indeed, "African indigeneity" has been historically erased "through linguistic sleight of hand," thus revealing the kinds of racial binaries and patterns of "antiBlackness" that propagate whiteness (Byrd 2019, p. 211; Dumas and Ross 2016, pp. 425-26). While this essay addresses historical episodes of Black and Indigenous peoples in separate sections, this does not mean these community identity designations should be taken as inherently separate categories. A full explanation of this point is beyond the scope of this essay and has been addressed by numerous scholars including Mays (2021). Second, Black, and Indigenous peoples share foundational 
connections to the land occupied by the United States. They have been victims of land theft, exploited labor, and identity erasure (Dumas and Ross 2016; Eagle Shield 2020; Harris 2019; Tuck and Ree 2013). Third, Black and Indigenous discourses and histories engender understanding concerning the structuring of white supremacy (Lethabo King 2019). In US history this has particularly been the case. Mays (2021, p. 43) has argued that "African and Indigenous peoples ... have been intimately linked" considering they share an ongoing struggle for emancipation and survival. They share in the project of educating and organizing for a joyous present and decolonized future (Eagle Shield 2020, pp. 11-12; Tachine and Ewing 2021).

Herein, I will use ghosts, phantasms, poltergeists, and specters not as metaphor, but to illuminate the actual material haunting nature of whiteness. In this examination, ghosts are defined as the historical and modern ideologies, policies, and practices that haunt the lands we live on, and those that appear wherever members of the dominant cultural group are present to ensure the propagation of oppressive traditions and status quos. What follows in this essay concentrates on the "historiospectography" - a term coined by Cohen (2006) and further developed by Zembylas (2013, p. 71) - to incite historical engagement with "notions of memory, justice, and (re)conciliation". This is done to elicit Black and Indigenous peoples' historical experiences with and resistance to the ghosts of whiteness. These sections contain reference to what I call hauntological pedagogies, an idea I'm adapting from Zembylas (2013, p. 83) "pedagogies of hauntology". I define these as a combination of Black and Indigenous communities' epistemological and spiritual ontologies that have historically sustained these communities. Additionally, I develop an argument focused on how these pedagogies have formed essential ways for Black and Indigenous peoples to collectively confront the ghosts of whiteness. I conclude the essay by invoking Du Bois's ([1903] 2014) notion of "spiritual strivings," to deduce both theoretical and practical approaches for educational leaders, practitioners, and theorists to promote racial and spiritual justice in defiance of white supremacy.

As a person who has been socialized into and navigates the world as white and is a settler in the U.S., I recognize that my perspectives on whiteness and the liberatory educational and spiritual praxes of Black and Indigenous peoples are and should be subject to scrutiny. I do not claim to have an absolute understanding of the historical and ongoing impact of whiteness on the communities of people its sought to oppress. To suggest otherwise would be to "perform conceptual violence," as Leonardo $(2016$, p. 8) has written. Instead, this essay reflects two commitments to my work as an educational leader, practitioner, and theorist. First, it reflects my personal dedication to "listen" to (Leonardo 2016, p. 8) and stand in solidarity with the subaltern in the pursuit of an abolitionist, decolonized future. Second, as the "'pathway' out of whiteness is unclear," what follows is a contribution to my own (and hopefully others') "racial [and spiritual] transformation" (Howard 2006, p. 139; Leonardo 2016, p. 12). I note this, while understanding that as a white person, identity struggle and transformation is an active project rather than a stagnant event (Leonardo 2009, p. 186; Winant 1997).

\section{2. "From Hell": Ghosts from Enslavement to Brown v. Board and Beyond}

The ghostly "ideology of education and society" propagated by the white Southern planter class in the U.S. from the 17th to the mid-19th century loomed over the American Republic eerily, violently (Anderson 1988, p. 4; Du Bois [1935] 1998). The epistemology they cultivated and exported across what they came to call North America was white supremacy and the enslavement of African peoples whom they forced to live and toil under inhuman conditions as they made American capitalism (Baptist 2014, p. 421; Desmond 2019, pp. 30-35). This also included the creation of "skin color ... the projection of the not-me" that has haunted the U.S. and the rest of the globe ever since (Morrison 1992, p. 38). Central to the Planters' project was the coerced labor, dehumanization, discombobulation, and displacement of African peoples (Baptist 2014; Berry 2017). Considered a threat to white Planters' "property rights," white enslavers acted in 1711, as demonstrated by 
South Carolina's colonial legislature, to pass public statutes preventing enslaved Africans from transcending their bonded "state and condition" (Fraser 2010, pp. 5-6). The law assuaged white fears of having to abandon their racist hermeneutic of the Christian Bible and protected their "possessive investment" in their human chattel (Fraser 2010, p. 5; Lipsitz 1998). Armed with this "spectro-theology" (Caputo 2020), white Euro-American Christian Planters sought to lock African peoples into perpetual servitude, despite their educational gifts, literacy skills, conversion to Christianity, but most foundationally because of their humanity.

Yet both enslaved Black peoples in the South, and the Black freedmen and women of the north resisted and survived "the crucible of horror" (Baptist 2014, p. 433), and made every effort to "depart" from-or excise themselves of-classist, racist, and sexist philosophies and practices passed through time like lingering ghosts from the white supremacist enslavers before and after Emancipation (Anderson 1988, pp. 4-5; Baumgartner 2019). Song, story, community action, literacy, and grassroots organizing formed the basis of the critical and revolutionary pedagogy of Black folks who resisted the specter-like epistemology of whiteness (Allen et al. 1867; Dixson et al. 2017; Greenberg 2003; Madyun and Witherspoon 2010; Robertson 2000). Most often, these liberatory hauntological pedagogies were developed in "the Negro Church, ... a centre [sic] of social life" (Du Bois [1899] 1996, p. 201) for Black folks. Du Bois ([1899] 1996) also described the ways the Black Church operated as a space that had more than a religious function, "it [was] a government of men" (p. 210). "Church pulpits" played foundational roles in the production of knowledge and spiritual practices for Black women, too (Bay et al. 2015, p. 4). Furthermore, the education and spiritual practices Black communities developed historically "transcend[ed] the boundaries of institutional religion," forging what Dantley has called "critical spirituality" (Dantley 2010, p. 214).

"History," while it "doesn't repeat itself," as historian Edward Baptist has written, "it [can] breed new monsters" (Baptist 2014, p. 435). The ghosts of whiteness have consistently contested Black folks' attempts to construct and attend schools, or otherwise establish spaces for the education and spiritual nourishment of their communities since Emancipation and Civil War Reconstruction. (Alridge et al. 2021; Anderson 1988, 2016; Blum 2007, pp. 141-45; Du Bois [1935] 1998; Span 2010). Indeed, at every juncture in U.S. history, where Black men, women, and children have fought to secure space to educate old and young alike in liberatory epistemology, literacy, and spirituality, ghosts of the white Euro-American Christian sort have been present.

In the 1860s and 1870s, the Ku Klux Klan-often referred to among Klan members themselves and other white supremacist sympathizers as "the ghosts of the Confederate dead" (McWhiney and Simkins 1951, p. 110)_wreaked havoc across the American South. As they rode together, the white bank clerks, government officials, shopkeepers, and even teachers, claimed "they came from hell," and "wore disguises designed to create that illusion" (McWhiney and Simkins 1951, p. 111). In essence, the Klan adorned white robes and hoods with the intent of purposing a shared Christian ontology to inflict psychological terror on their victims. Yet, it was less their "ghostly robes" (McWhiney and Simkins 1951, p. 110), and more so the Klan's "ghostly decorations" - their weapons, including their guns, knives, dynamite, and fire from burning crosses (fire being a traditional depiction of hell)that were used to inflict physical violence and spread fear across the land. These ghosts were committed to dispossessing Black peoples of their academic and sacred spaces and preventing them from propagating a liberatory epistemology that defied white supremacist aims and visions.

The Klan's hauntings across the American South ultimately proved unsuccessful in damaging post-Reconstruction African Americans' collective resolve and their commitment to literacy and full citizenship in the U.S. (Anderson 1988, pp. 274-75; Span 2010, pp. 163-64). However, the ghostly violence illuminated white, mostly Christian lynch mobs' dedication to what Blum (2007, p. 141) refers to as the "God of whiteness". The Klan and their sympathizers engineered a white supremacist theology around their brand of Christian epistemology to justify their participation in killings, which they referred to as 
"sacrifices," or a form of "atonement," that justified their belief in "the sanctity" of their white skin, racial segregation, and imagined superiority (Blum 2007, p. 143).

These ghosts continued to haunt the institutions and social systems that Black children and youth relied on. The ghosts' intent was to entrench their assertion to property rights in Black labor (Harris 1993), claim an imagined racial superiority, and attempt to exert control over the epistemology and spiritual ontologies (or hauntological pedagogies) passed on from Black teachers to their students across time and space (Bethune 1935; Du Bois 1935; Givens 2021; Tillman 2004; Woodson [1933] 2013). The historic ghosts and even their contemporaries abound. The following examples reflect a small sampling of antiBlack episodes in U.S. educational history: white, Klan-affiliated teachers and administrators at the Hampton-Tuskegee Industrial School in the 1930s (Anderson 1988, pp. 273-74); the white mothers who led "massive resistance" campaigns across the American South against the Supreme Court's 1954 ruling in Brown v. Board of Education to racially integrate public schools (Gillespie McRae 2018); calls for racially segregated learning spaces-disguised in the public sphere as "school choice" - in the 1960s and 1970s from economists like Milton Friedman (Hale 2021); the creation of so-called "segregation academies" that educated an estimated 500,000 white students in racially discriminatory private school settings in the decades after Brown (Champagne 1973); and the contemporary culture wars involving white parents opposed to K-12 public school curriculums they falsely believe are teaching tenets of critical race theory, or are otherwise emphasizing white victimization over teachers and professors addressing histories of racism and violence in the U.S. (Frank and Laats 2021; Woodruff 2021). Frank and Laats (2021) in particular, have demonstrated that these contemporary echoes of white supremacist fights from history-haunting education spaces like ghosts-are just as full of racial and religious oriented vigor as they were in centuries past.

The ghosts that haunted the lands and lives of Black folks seeking to educate themselves in the 19th and 20th centuries have shapeshifted anew in the 21st century, yet these apparitions have taken on more deceiving forms. This is largely due to the ways antiBlackness functions within white supremacist political and social systems to which schools are inextricably linked (Dumas 2016; Dumas and Ross 2016, p. 425). To confront the ghosts of whiteness, one might consider Dumas (2016, p. 17) argument, that "teachers, administrators, and district leaders" should reckon with antiBlackness that has been and continues to be directed at "Black bodies, [B]lackness, and Black historical memories in and of ... school communit[ies]". (Dumas 2016, p. 17). An additional sampling of contemporary antiBlack episodes in U.S. schools follow in the paragraph below. They illuminate the thesis Bell (1992) put forward concerning the "permanence of racism," and reiterate his point that "we live in a society in which racism has been internalized and institutionalized to the point of being an essential and inherently functioning component of society" (Bell 1991, p. 88).

The ghastliness, oppression, and "sanctification" of whiteness (Blum 2007, p. 141) appear in the demographic questions on race and ethnicity asked of each student who registers to attend their neighborhood K-12 school, for financial aid, or even to comply with U.S. Constitutional census requirements (Painter 2010, p. 384). These ghosts reveal their weapons from their metaphorical robes each time a school serving predominantly Black children-whether in the American South (Duncan-Shippy 2019), the Midwest (Ewing 2018; Hall 2020), the Mountain West (Horsford 2016), or elsewhere-is closed and its resources moved "around the system without increasing achievement" (Horsford et al. 2019, pp. 6-7). This includes these schools' teachers and their community sustaining pedagogies (LadsonBillings and Anderson 2021), as well as the life-sustaining resources of food and safety that racially and spatially motivated politics of school closures eliminate (Diem and Welton 2021). The specters of whiteness have also materialized in the form of securing public funding - often referred to as vouchers- to subsidize the racist, homophobic, and white supremacist agendas of many Evangelical and politically conservative Christian private schools across the U.S. (Baker and Green 2020). This has largely been made possible due to 
the ahistorical reading of Constitutional law in the Supreme Court's decision of Espinoza v. Montana Department of Revenue (2020).

Because the ghosts of whiteness form a "pervasive part of the American landscape," Dixson and Anderson (2017a, pp. 4-5) encourage African Americans and their allies to "listen" to the songs of the past "with a new ear". Another way of framing this, is that there is a need to engage hauntological pedagogies to confront whiteness. To dispossess African American lives and futures from the horrors of the ethereal, these critical scholars affirm that resistance should be grounded in the literature, songs, stories, theories, and movements that have continually pushed back against the dismaying nature of white supremacy for centuries (Bell 1992, 2004; Dixson and Anderson 2017b).

\section{3. "In the Light of Christian Civilization": The Haunting of Turtle Island}

The ghosts of whiteness have haunted Indigenous peoples in North America since before the U.S. nation was metaphorically "birth[ed]," considering that "the [Christian] church and [Euro-American] state ... acted as coconspirators in the theft of Native America" (Grande 2015, p. 15). The racial logics of Euro-American settlers from the 15th through the 20th century were tied to an aggressive "Protestant ideology" (Adams 2008, p. 12). This ideology informed white Christians' colonization efforts from their inception. It was an ideology founded on possessing Indigenous lands and invalidating Indigenous knowledges for the socioeconomic and political benefit of those deemed "white" enough for their entitlement (Grande 2015, pp. 183-90; Grosfoguel 2013; Mills 1997, pp. 12-14; Wynter 2003). Kelley (2021); Mills (1997); Robinson (2005) have argued that the predecessors of Locke and Kant-oriented Euro-American Christian missionaries perfected their colonization tactics in Europe prior to their North American arrival. They did so, the scholars assert, by waging epistemic, spatial, and spiritual genocide among the Jews, Muslims, and Pagans. In effect, the French Huguenots, Spanish Catholics, and British Protestants arrived at North American shores in the 15th and 16th centuries like ghosts with unfinished business. Grande (2015, pp. 15-16) details how over the subsequent centuries, "full-service educational systems" determined to "de-Indigenize" Native children and youth. Indeed, the mission of some of the U.S.'s earliest educational institutions-including Harvard (1636), the College of William and Mary (1693); Dartmouth (1769) —were committed to dual charges of "civilizing" and "Christianizing" North America's Native peoples (Grande 2015, pp. 15-16).

Ghosts have taken the form of U.S. jurisprudence and legislation, revealing the horrific intent by white, Euro-American settlers to deprive Indigenous peoples and their children of epistemic, spatial, and spiritual sovereignty. The passing of a Virginia Statute on "The Education of Indian Children Held Hostage" in 1656, for instance, demonstrates white EuroAmerican settlers' possessive interest in reorienting Indigenous worldviews. It was their intent to center Christian ethics and morals, dispossess Indigenous peoples of their lands, languages, and relationships, and to inculcate the capitalistic labor classes and principles taught by white missionaries and colonial settlers (Fraser 2010; Grande 2015, pp. 50-51, 54-55; Kaestle 2011; Urban et al. 2019, pp. 10-11). The U.S. Congress passed the "Civilization Fund Act" in 1819 for the purpose of "civilizing" North American Indigenous peoples in "agriculture," and in "reading, writing, and arithmetic" (Fraser 2010). However, Indigenous children's schooling on the U.S. frontier in private homes and at Christian missions was merely "a place of 'becoming white'" (Peshkin 1997, p. 117). Furthermore, Grande (2015) illustrates the ghostly nature of U.S. Supreme Court Chief Justice John Marshall's opinion in Johnson v. McIntosh (1823), haunting Indigenous peoples of the past as well as in the present. Marshall's nineteenth century opinion highlighted and elevated the so-called "Doctrine of Discovery" - the Medieval European law that established rules and regulations for the "discovery," "finding," and "right of occupancy" to land in the western hemisphere- to rational jurisprudence in the modern world (Grande 2015, pp. 55-56). True to form, the poltergeists of the juridical past, continue to "haunt the political and legal domain" of the U.S. They have effectively established a "landlord-tenant relationship" between the U.S. 
federal government and Native nations and tribes that continues to this day (Grande 2015, p. 56; Harris 1993).

Next to African enslavement, one of the most horrific instances of haunting induced by the ghosts of whiteness in the U.S. were the creation and operation of residential boarding schools. Most famous among these schools, which eventually dotted North America (Urban et al. 2019, p. 146), was the off-reservation school located at Carlisle, Pennsylvania after which other so-called "schools" were modeled (Adams 1995; Reyhner and Eder 2004). The haunting of Carlisle was epistemic and spiritual assimilation of Native children to "white" society by instructing them "in the light of Christian civilization" (Adams 2008, p. 20). "Reclothed, regroomed, and renamed" (Reyhner and Eder 2004, p. 168), Indigenous children's realities were distorted by the ghosts of whiteness, which also attempted to replace Indigenous spiritual rituals with those based on a white supremacist Christian theology (Adams 1995; Deloria 2003; Standing Bear 2006). Carlisle—and other "schools" modeled after it-also served white supremacy's pernicious spatial ends by further dispossessing Indigenous families of their lands in order to "gain access to [Native] labor and resources" (Adams 2008, pp. 26-30; Grande 2015, p. 23).

Persistent efforts by the phantom "Wasichus" —or white colonizing settlers (Neihardt 1979; Estes 2020, pp. 46, 111) - to eradicate Native American cultural and religious ceremonies through the 1883 Code of Indian Offenses and subsequent corollaries (Treuer 2019), and otherwise dispossess Native peoples, proved futile (Adams 1995; Estes 2020; Grande 2015; Ostler 2019). Through Indigenous resistance across time and space, Native peoples' identities, relationship to the land, human, and non-human relatives, as well as their spiritual ceremonies and rituals remain presently intact (Estes 2020; Grande 2015; Villegas et al. 2008). This has been most recognizable through The Ghost Dance, but more recently through the \#NoDAPL Movement-e.g., the Indigenous women led movement against the Dakota Access Pipeline (Estes 2020; Keene 2020; Mackey 2018; Mays 2021). Contrary to popular white settler understanding, the Ghost Dance-begun in the 1870s by Paiute prophet Wodziwob-was part of an "anticolonial theory and movement" that resisted the ghost world created by white supremacy and colonialism by presenting "visions" of a pan-Indigenous "anti-colonial future" (Estes 2020, pp. 124-25). In every way, the Ghost Dance religion, informed the Indigenous resistance movement in 2016-2017 at Standing Rock against the Dakota Access Pipeline (Estes 2020, p. 131). The Ghost Dance thus presents further opportunities for exploring Indigenous resistance, flexibility, expertise, and epistemology as decolonial and hauntological pedagogy and theory (Keene 2020, pp. 109-10; Mackey 2018).

The ghosts that have for centuries haunted the lands and lives of Indigenous peoples on "Turtle Island" - or North America to numerous but not all Indigenous nations (Paris 2020, p. 23) - are unsurprisingly discontent, and continue to morph in the 21st century. Indigenous peoples contemporarily face issues as they struggle for educational sovereignty, including educating administrators and instructors at P-20 educational institutions about the histories and needs of, as well as institutional responsibilities towards, Indigenous students and their communities (Brayboy et al. 2015, p. 6). The ghosts of whiteness also cast a shadow over Indigenous language revitalization efforts, as demonstrated by the inconsistencies of the federal government's No Child Left Behind (NCLB) policy. NCLB notoriously called for Indigenous language revitalization, but punished schools enrolling Indigenous students by taking away money and essential resources due to poor performance on standardized tests (Reyhner and Sing 2015, pp. 26-27). In response to this, educational leader and Indigenous scholar, Mackey (2018), has suggested that to rely exclusively on U.S. education policy to assist Indigenous nations and peoples in education related efforts is essentially to live in a state of futility and torment. In effect, she argues that overreliance on federal intervention is to be haunted by the ghosts of whiteness. Indigenous leaders encourage increased solidarity with Indigenous peoples and educators who advocate "place-based" pedagogies centered on community resources and needs, kinship, 
and relationality, relying on intergenerational epistemologies, and reflecting on Indigenous resistance as a guide for "protecting what is sacred" (Garcia et al. 2020, pp. 90-92, 97).

\section{4. "Spiritual Strivings": Leveraging "Second-Sight" to See "the Other World"}

In addition to theorizing the concept of whiteness as a socially constructed power relationship that took on religious qualities (Du Bois [1920] 1999), Du Bois theorized the concept of "double-consciousness," or "second-sight," as he also referred to it (Du Bois [1903] 2014). In his philosophical cogitation, the ability to "look at one's self [sic] through the eyes of others ... measuring one's soul by the tape of a world that looks on [at them] in amused contempt and pity" is a unique "gift" that African Americans are "born with" (Du Bois [1903] 2014, p. 5). While he wrote about and to Black communities, Du Bois would likely have been comfortable extending this meditation to any racially otherized non-white person. Du Bois described this "gift" as both a curse and a blessing, but one that intensified the "spiritual strivings" and yearnings of racially oppressed peoples for a better world-a "mountain path to Canaan" (Du Bois [1903] 2014, p. 7). To arrive at a place where the earth's inhabitants can see "the other world," as was Du Bois's ([1903] 2014, p. 4) prophetic way of describing an abolitionist decolonized future, the ghosts of whiteness must be exorcised. White people have the largest responsibility in dismantling the "white supremacist political system" (Mills 1997, p. 1) that they have a "possessive" investment in upkeeping (Leonardo 2009, p. 81; Lipsitz 1998). To expel the ghosts of whiteness, or dismantle racial and spiritual injustice, then, is to "undo the self ... and come to terms with a reconstructed identity" (Leonardo 2009, p. 186). In essence, to engage in hauntological pedagogy. Listening to and learning from the hauntological pedagogies of the racially and spiritually oppressed provide at least one invaluable strategy for engaging in this project (Du Bois [1903] 2014; Eastman [1911] 1980; Zembylas 2013, p. 83). Committing to solidarity with the racially and spiritually oppressed provides another strategy for white people desirous to grapple with the haunting "terror" of whiteness (Bell 1997, p. 169; Dixson et al. 2017; Leonardo 2009, p. 185; Roediger 1994; Winant 1997).

Taking the above into account, the liberatory desires of enslaved Africans who sang the following verse is instructive:

\section{I looked over Jordan and what did I see \\ Comin' for to carry me home? \\ A band of angels comin' after me, \\ Comin' for to carry me home.}

A critical reading of this African spiritual, Dixson and Anderson (2017a, p. 3) reveal, invites readers to consider the full weight and "multiple levels" of the contexts of enslavement (or historical oppression), but also "the possibility of escape" (or an emancipated future). In essence, methods for envisioning a racially and spiritually just world can be found in the "transcendent" messaging of those whom the ghosts of white supremacy have historically and systematically marginalized. This methodology includes working with people "on the bottom" and learning to "sing a new song," so-to-speak (Dixson and Anderson 2017a, pp. 3, 5-6). This entails recognizing racism as an endemic facet of American life and working collectively to challenge claims and educational policies that center supposed racial neutrality or claim to adhere to meritocracy (Ladson-Billings and Tate 1995). This also includes understanding the financial devastation whiteness's ghosts have wrought on African American communities and their educational endeavors and can include mobilizing to seek reparations (Green et al. 2021). It means constantly questioning "whose knowledge counts and whose knowledge is discounted" in every schooling or educational environment (Yosso 2005, p. 69). It involves legitimizing the stories of Black people and other persons of color that "counter the dominant discourse" (Dixson and Anderson 2017b, p. 35). Finally, this means rendering visible that which the ghosts of whiteness have rendered "invisible" (Ellison 1952). This could include, for example, the "artistic phenomenon" of Hip Hop that signals both the real conditions and aspired futures 
of African Americans' social, economic, and political lives (Alridge 2005; Alridge and Stewart 2005, p. 190).

In addition, much concerning antiracist, anti-colonial "visions of the other world" (Neihardt 1979, p. 243) and steps for radically reshaping it can be gained from close study of Indigenous epistemology, theory, and praxis. In fact, this is what Estes, an Indigenous historian and social activist, means when he writes that "[Indigenous] history is the future" (Estes 2020). Other approaches can involve amplifying and celebrating Indigenous survivor stories (Grande 2015, p. 242; Smith 2021, pp. 166-67) and "listening to, feeling, and learning from the land" we inhabit (Smith 2021, pp. 206-7). Additionally, this might look like learning to do what Indigenous scholars like Smith (2021, pp. 192-93) and Wall Kimmerer (2020) call "living in relation"- a practice of engaging in "reciprocity" with both animate and inanimate "forces" or "energies". Furthermore, educational institutions can "explore the flexibility of institutionalizing traditional knowledges" (Eagle Shield 2020, p. 65), as well as securing and sustaining high levels of financial funding and administrative support for the revitalization of Indigenous languages and traditions (Eagle Shield 2020; Faircloth and Tippeconnic 2010; Reyhner and Sing 2015). It also means recognizing that many contemporary Indigenous peoples are interested in moving beyond institutionally popular "land acknowledgements" and seeking the sort of epistemic, spatial, and spiritual justice advocated for by the \#LandBack social movement and Indigenous scholars (Tuck and Yang 2012, pp. 25, 35).

Whereas the ghosts in the Euro-American Christian hermeneutic haunt, linger, and torment their victims enacting a form of spiritual death, engaging the hauntological pedagogies of the oppressed (Freire [1970] 2018; Zembylas 2013) has the power to transform education spaces. The hauntological pedagogies of Black and Indigenous peoples can expand the range of belief, expression, and thought (Horsford et al. 2019) that have historically taken precedent in formal schooling environments. With this knowledge, coupled with "commitment" (Bell 1991, p. 91), educational leaders, practitioners, and theorists alike are more equipped to confront the ghosts of whiteness. In solidarity with the oppressed (Freire [1970] 2018), educators "striving" (Du Bois [1903] 2014, p. 30) collectively can disrupt the white supremacist ghost world (Estes 2020, pp. 124-25) to approach an epistemically, racially, spatially, and spiritually just world.

Funding: This research received no external funding.

Institutional Review Board Statement: Not applicable.

Informed Consent Statement: Not applicable.

Data Availability Statement: Not applicable.

Conflicts of Interest: The author declares no conflict of interest.

\section{Note}

In this essay, I have elected to follow the tradition of using "Black" to indicate those peoples of African descent, part of the larger African Diaspora, who live in the United States and developed rich intellectual and spiritual traditions despite and in spite of enslavement, legalized racial classifications, and the myriad structural forms of white supremacy in the U.S. (Alridge et al. 2021).

\section{References}

Adams, David Wallace. 1995. Education for Extinction: American Indians and the Boarding School Experience, 1875-928. Lawrence: University Press of Kansas.

Adams, David Wallace. 2008. Fundamental considerations: The deep meaning of Native American schooling, 1880-900. In Indigenous Knowledge and Education: Sites of Struggle, Strength, and Survivance. Edited by Malia Villegas, Sabina Rak Neugebauer and Kerry R. Venegas. Cambridge: Harvard Educational Review, pp. 9-39.

Allen, William Francis, Charles Pickard Ware, and Lucy McKim Garrison, eds. 1867. Slave Songs of the United States. Bedford: Applewood Books.

Alridge, Derrick P. 2005. From civil rights to hip hop: Toward a nexus of ideas. The Journal of African American History 90: $226-52$. [CrossRef] 
Alridge, Derrick P., and James B. Stewart. 2005. Introduction: Hip hop in history: Past, present, and future. The Journal of African American History 90: 190-95. [CrossRef]

Alridge, Derrick P., Cornelius L. Bynum, and James B. Stewart. 2021. The Black Intellectual Tradition: African American thought in the Twentieth Century. Urbana: University of Illinois Press.

Anderson, James D. 1988. The Education of Blacks in the South, 1860-935. Chapel Hill: University of North Carolina Press.

Anderson, Carol. 2016. White Rage: The Unspoken Truth of our Racial Divide. New York: Bloomsbury.

Baker, Bruce D., and Preston C. Green III. 2020. The post-Espinoza end game. School Finance 101, July 29. Available online: https: //schoolfinance101.wordpress.com/2020/07/29/the-post-espinoza-end-game/ (accessed on 18 October 2021).

Baptist, Edward E. 2014. The Half Has Never Been Told: Slavery and the Making of American Capitalism. New York: Basic Books.

Baumgartner, Kabria. 2019. In Pursuit of Knowledge: Black Women and Educational Activism in Antebellum America. New York: New York University Press.

Bay, Mia E., Farah J. Griffin, Martha S. Jones, and Barbara D. Savage. 2015. Toward an Intellectual History of Black Women. Chapel Hill: The University of North Carolina Press.

Bell, Derrick. 1991. Racism is here to stay: Now what? Howard Law Journal 35: 79-94.

Bell, Derrick. 1992. Faces at the Bottom of the Well: The Permanence of Racism. New York: Basic Books.

Bell, Derrick. 1996. Gospel Choirs: Psalms of Survival in an Alien Land Called Home. New York: Basic Books.

Bell, Michael Mayerfeld. 1997. The ghosts of place. Theory and Society 26: 813-36. [CrossRef]

Bell, Derrick. 2004. Silent Covenants. Brown v. Board of Education and the Unfulfilled Hopes for Racial Reform. New York: Oxford University Press.

Berry, Daina Ramey. 2017. The Price for Their Pound of Flesh: The Value of the Enslaved, from Womb to Grave, in the Building of a Nation. Boston: Beacon Press.

Bethune, Mary McLeod. 1935. The Association for the Study of Negro Life and History: Its contribution to our modern life. The Journal of Negro History 20: 406-10. [CrossRef]

Blum, Edward J. 2007. W.E.B. Du Bois: American Prophet. Philadelphia: The University of Pennsylvania Press.

Brayboy, B. M. J. 2005. Toward a tribal critical race theory in education. The Urban Review 37: 425-6. [CrossRef]

Brayboy, Bryan McKinley Jones, Susan C. Faircloth, Tiffany S. Lee, Margaret J. Maaka, and Troy A. Richardson. 2015. Sovereignty and education: An overview of the unique nature of Indigenous education. Journal of American Indian Education 54: 1-9.

Butler, Judith, and Athena Athanasiou. 2013. Dispossession: The Performative in the Political. Malden: Polity Press.

Byrd, Jodi A. 2019. Weather with you: Settler colonialism, antiblackness, and the grounded relationalities of resistance. Critical Ethnic Studies 5: 207-14. [CrossRef]

Caputo, John D. 2016. Teaching the event: Deconstruction, hauntology, and the scene of pedagogy. In The Pedagogics of Unlearning. Edited by Aidan Seery and Éamonn Dunne. Santa Barbara: Punctum Books, pp. 111-30.

Caputo, John D. 2020. In Search of Radical Theology: Expositions, Explorations, Exhortations. New York: Fordham University Press.

Champagne, Anthony M. 1973. The segregation academy and the law. The Journal of Negro Education 42: 58-66. [CrossRef]

Clarke, Roger. 2012. A Natural History of Ghosts: 500 Years of Hunting for Proof. New York: Penguin Books.

Cohen, Sande. 2006. History Out of Joint: Essays on the Use and Abuse of History. Baltimore: Johns Hopkins University Press.

Dantley, Michael E. 2010. Successful leadership in urban schools: Principals and critical spirituality, a new approach to reform. The Journal of Negro Education 79: 214-19.

Davis, Colin. 2005. Ét at Présent: Hauntology, spectres and phantasms. French Studies 59: 373-79. [CrossRef]

Davis, Julie L. 2013. Survival Schools: The American Indian Movement and Community Education in the Twin Cities. Minneapolis: University of Minnesota Press.

Deloria, Vine, Jr. 2003. God Is Red: A Native View of Religion. Denver: Fulcrum Publishing.

Derrida, Jaques. 1994. Specters of Marx: The State of the Debt, the work of Mourning, and the New International. Translated by Peggy Kamuf. New York: Routledge. First published 1993.

Desmond, Matthew. 2019. Capitalism. The New York Times Magazine, August 18, pp. 30-35.

Diem, Sarah, and Anjalé D. Welton. 2021. Anti-Racist Educational Leadership and Policy: Addressing Racism in Public Education. New York: Routledge.

Dixson, Adrienne D., and Celia K. Rousseau Anderson. 2017a. Critical race theory and education: Singing a "new" song. In Critical Race Theory in Education: All God's Children got a Song, 2nd ed. Edited by Adrienne D. Dixson, Celia K. Rousseau Anderson and Jamel K. Donnor. New York: Routledge, pp. 1-8.

Dixson, Adrienne D., and Celia K. Rousseau Anderson. 2017b. And we are still not saved: 20 years of CRT and education. In Critical Race Theory in Education: All God's Children got a Song, 2nd ed. Edited by Adrienne D. Dixson, Celia K. Rousseau Anderson and Jamel K. Donnor. New York: Routledge, pp. 32-54.

Dixson, Adrienne D., Celia K. Rousseau Anderson, and Jamel K. Donnor, eds. 2017. Critical Race Theory in Education: All God's Children Got a Song. New York: Routledge.

Du Bois, W. E. B. 1996. The Philadelphia Negro: A Social Study. Philadelphia: The University of Pennsylvania Press. First published 1899.

Du Bois, W. E. B. 2014. The Souls of Black Folk. Narragansett: Millennium Publications. First published 1903.

Du Bois, W. E. B. 1999. Darkwater: Voices from within the Veil. Mineola: Dover Thrift Editions. First published 1920.

Du Bois, W. E. B. 1998. Black Reconstruction. New York: The Free Press. First published 1935.

Du Bois, W. E. Burghardt. 1935. Does the Negro need separate schools? The Journal of Negro Education 4: 328-35. [CrossRef] 
Dumas, Michael J. 2016. Against the dark: AntiBlackness in education policy and discourse. Theory Into Practice 55: 11-19. [CrossRef]

Dumas, Michael J., and Kihana Miraya Ross. 2016. "Be real Black for me": Imagining BlackCrit in education. Urban Education 51: 415-42. [CrossRef]

Duncan-Shippy, Ebony M., ed. 2019. Shuttered Schools: Race, Community, and School Closures in American Cities. Charlotte: Information Age Publishing, Inc.

Eagle Shield, Alayna. 2020. Nağí Unkíčhopi (Calling our spirits back) through language and culture from Očhéthi Šakówin and beyond. In Education in Movement Spaces. Edited by Alayna Eagle Shield, Django Paris, Rae Paris and Timothy San Pedro. New York: Routledge, pp. 57-66.

Eastman, Charles A. (Ohiyesa). 1980. The Soul of the Indian: An Interpretation. Lincoln: University of Nebraska Press. First published 1911. Ellison, Ralph. 1952. Invisible Man. New York: Vintage Books.

Espinoza v. Montana Department of Revenue. 2020. 591 U.S._2020. Available online: https://www.oyez.org/cases/2019/18--1195 (accessed on 18 October 2021).

Estes, Nick. 2020. Our History Is the Future: Standing Rock versus the Dakota Access Pipeline, and the Long Tradition of Indigenous Resistance. New York: Verso Books.

Ewing, Eve L. 2018. Ghosts in the Schoolyard: Racism and School Closings on Chicago's South Side. Chicago: The University of Chicago Press.

Faircloth, Susan C., and John W. Tippeconnic, III. 2010. The Dropout/Graduation Rate Crisis among American Indian and Alaska Native students. In The Civil Rights Project at UCLA and The Pennsylvania State University Center for the Study of Leadership in American Indian Education. Available online: https:/ / files.eric.ed.gov/fulltext/ED511323.pdf (accessed on 16 October 2021).

Frank, Gillian, and Adam Laats. 2021. This Critical Race Theory Panic is a Chip off the Old Block. Slate Magazine. June 18. Available online: https://slate.com/news-and-politics/2021/06/critical-race-theory-curriculum-panics-history.html (accessed on 18 October 2021).

Fraser, James W., ed. 2010. The School in the United States: A Documentary History, 2nd ed. New York: Routledge.

Freire, Paulo. 2018. Pedagogy of the Oppressed 50th Anniversary Edition. Translated by Myra Bergman Ramos. New York: Bloomsbury Academic. First published 1970.

Garcia, Jeremy, Valerie Shirley, Sweeney Windchief, and Timothy San Pedro. 2020. Pedagogy of solidarity: Hope and promise from Indigenous movement spaces. In Education in Movement Spaces. Edited by Alayna Eagle Shield, Django Paris, Rae Paris and Timothy San Pedro. New York: Routledge, pp. 87-98.

Gillborn, David. 2004. Anti-racism: From policy to praxis. In The RoutledgeFalmer Reader in Multicultural Education. Edited by David Gillborn and Gloria Ladson-Billings. New York: RoutledgeFalmer, pp. 35-47.

Gillborn, David. 2005. Education as an act of white supremacy: Whiteness, critical race theory, and education reform. Journal of Education Policy 20: 485-505. [CrossRef]

Gillespie McRae, Elizabeth. 2018. Mothers of Massive Resistance: White Women and the Politics of White Supremacy. New York: Oxford University Press.

Givens, Jarvis R. 2021. Fugitive Pedagogy: Carter G. Woodson and the Art of Black Teaching. Cambridge: Harvard University Press.

Grande, Sandy. 2015. Red Pedagogy: Native American Social and Political Thought. Lanham: Rowman \& Littlefield.

Green, Preston C., III, Bruce D. Baker, and Joseph O. Oluwole. 2021. School finance, race, and reparations. Washington and Lee Journal of Civil Rights and Social Justice 27: 484-523. [CrossRef]

Greenberg, Kenneth S., ed. 2003. Nat Turner: A Slave Rebellion in History and Memory. New York: Oxford University Press.

Grosfoguel, Ramón. 2013. The structure of knowledge in westernized universities: Epistemic racism/sexism and the four genocides/epistemicides of the long 16th century. Human Architecture: Journal of the Sociology of Self-Knowledge 11: 73-90.

Hale, Jon N. 2016. The Freedom Schools: Student Activists in the Mississippi Civil Rights Movement. New York: Columbia University Press.

Hale, Jon N. 2021. The Choice We Face: How Segregation, Race, and Power have Shaped America's Most Controversial Education Reform Movement. Boston: Beacon Press.

Hall, Horace R. 2020. Ghosts of Black captivity and the curriculum of Freedom Square. In Education in Movement Spaces. Edited by Alayna Eagle Shield, Django Paris, Rae Paris and Timothy San Pedro. New York: Routledge, pp. 113-18.

Harris, Cheryl. 1993. Whiteness as property. Harvard Law Review 106: 1707-91. [CrossRef]

Harris, Cheryl I. 2019. Of Blackness and Indigeneity: Comments on Jodi A. Byrd's “Weather with you: Settler colonialism, antiblackness, and the grounded relationalities of resistance". Critical Ethnic Studies 5: 215-27. [CrossRef]

Hartman, Andrew. 2004. The rise and fall of whiteness studies. Race E Class 46: 22-38.

Hartman, Geoffrey. 2010. Gods, ghosts, and shelley's 'Atheos'. Literature E Theology 24: 4-18.

Hooks, Bell. 1997. Representing whiteness in the black imagination. In Displacing Whiteness. Edited by Ruth Frankenberg. Durham: Duke University Press, pp. 165-79.

Horsford, Sonya Douglass. 2016. Race and education in the mountain west: Charting new territory in America's racial frontier. In Race, Equity, and Education. Edited by Pedro Noguera, Jill Pierce and Roey Ahram. Cham: Springer, pp. 155-73.

Horsford, Sonya Douglass, Janelle S. Scott, and Gary L. Anderson. 2019. The Politics of Education in an Era of Inequality: Possibilities for Democratic Schooling. New York: Routledge.

Howard, Philip S. S. 2004. White privilege: For or against? A discussion of ostensibly antiracist discourses in critical whiteness studies. Race, Gender E Class 11: 63-79.

Howard, Gary R. 2006. We Can't Teach What We Don't Know: White Teachers, Multiracial Schools. New York: Teachers College Press. 
Johnson v. McIntosh. 1823. Johnson and Graham's Lessee v. McIntosh, 21 U.S. 543. Available online: https://supreme.justia.com/ cases/federal/us/21/543/ (accessed on 18 October 2021).

Jones, Robert P. 2021. White Too Long: The Legacy of White Supremacy in American Christianity. New York: Simon \& Schuster.

Kaestle, C. 2011. Pillars of the Republic: Common Schools and American Society, 1780-860. New York: Farrar, Straus and Giroux.

Keene, Adrienne. 2020. \#NoDAPL as pedagogy: Bringing the movement into the university classroom. In Education in Movement Spaces. Edited by Alayna Eagle Shield, Django Paris, Rae Paris and Timothy San Pedro. New York: Routledge, pp. 99-110.

Kelley, Robin D. G. 2017. The rest of us: Rethinking settler and native. American Quarterly 69: 274. [CrossRef]

Kelley, Robin D. G. 2021. On Reparations and Decolonization [Video]. YouTube, June 29. Available online: https:/ / www.youtube.com/ watch? $\mathrm{v}=\mathrm{b} 4$ uonGNC414 (accessed on 18 October 2021).

Ladson-Billings, Gloria, and James D. Anderson. 2021. Policy dialogue: Black teachers of the past, present, and future. History of Education Quarterly 61: 94-102. [CrossRef]

Ladson-Billings, Gloria, and William F. Tate IV. 1995. Toward a critical race theory of education. Teachers College Record 97: 47-68.

Leonardo, Zeus. 2002. The souls of white folk: Critical pedagogy, whiteness studies, and globalization discourse. Race Ethnicity and Education 5: 29-50. [CrossRef]

Leonardo, Zeus. 2009. Race, Whiteness, and Education. New York: Routledge.

Leonardo, Zeus. 2016. Tropics of whiteness: Metaphor and the literary turn in white studies. Whiteness and Education 1: 3-14. [CrossRef] Lethabo King, Tiffany. 2019. The Black Shoals: Offshore Formations of Black and Native Studies. Durham: Duke University Press.

Lipsitz, George. 1998. The Possessive Investment in Whiteness. Philadelphia: Temple University Press.

Lomawaima, K. Tsianina. 1994. They Called It Prairie Light: The Story of Chilocco Indian School. Lincoln: University of Nebraska Press.

Lynn, Marvin, and Adrienne D. Dixson, eds. 2013. Handbook of Critical Race Theory in Education. New York: Routledge.

Mackey, Hollie J. 2018. Contemporary decolonization: Dismantling policy barriers to systemic equity and self-determination. In The Wiley Handbook of Educational Policy, 1st ed. Edited by Rosemary Papa and Shadow W. J. Armfield. Weinheim: John Wiley \& Sons, Inc., pp. 267-87.

Madyun, Naim, and Noelle Witherspoon, eds. 2010. The role of spirituality, religion and the African American church on educational outcomes [Special issue]. The Journal of Negro Education 79: 199-442.

Mays, Kyle T. 2021. An Afro-Indigenous History of the United States. Boston: Beacon Press.

McCarty, Teresa L. 2002. A Place to be Navajo: Rought Rock and the Struggle for Self-Determination in Indigenous Schooling. Mahwah: Lawrence Erlbaum Associates.

McWhiney, H. Grady, and Francis B. Simkins. 1951. The Ghostly Legend of the Ku-Klux Klan. Negro History Bulletin 14: 109-12.

Mills, Charles. 1997. The Racial Contract. Ithaca: Cornell University Press.

Morrill, Angie, Eve Tuck, and the Super Futures Haunt Qollective. 2016. Before dispossession, or surviving it. Liminalities: A Journal of Performance Studies 12: 1-20.

Morrison, Toni. 1992. Playing in the Dark: Whiteness and the Literary Imagination. New York: Vintage Books.

Neihardt, John G. 1979. Black Elk Speaks: Being the life Story of a Holy Man of the Oglala Sioux as Told through John G. Neihardt (Flaming Rainbow). Lincoln: University of Nebraska Press.

Ostler, Jeffrey. 2019. Surviving Genocide: Native Nations and the United States from the American Revolution to Bleeding Kansas. New Haven: Yale University Press.

Painter, Nell Irvin. 2010. The History of White People. New York: W.W. Norton \& Company.

Paris, Django. 2020. Culturally sustaining pedagogies in the project of Black and Indigenous solidarities on Turtle Island. In Education in Movement Spaces. Edited by Alayna Eagle Shield, Django Paris, Rae Paris and Timothy San Pedro. New York: Routledge, pp. 23-29.

Peshkin, Alan. 1997. Places of Memory: Whiteman's Schools and Native American Communities. New York: Lawrence Erlbaum Associates.

Puett, Michael. 2014. Ritual disjunctions: Ghosts, philosophy, and anthropology, Chapter 9. In The Ground between: Anthropologists Engage Philosophy. Edited by Veena M. Das, Michael Jackson, Arthur Kleinman and Bhrigupati Singh. Durham: Duke University Press, pp. 218-33.

Reyhner, Jon, and Jeanne Eder. 2004. American Indian education: A history. Norman: University of Oklahoma Press.

Reyhner, Jon, and Navin Kumar Sing. 2015. Overcoming the legacy of assimilationist schooling. In Teaching Indigenous Students: Honoring Place, Community, and Culture. Edited by Jon Reyhner. Norman: University of Oklahoma Press, pp. 11-35.

Robertson, David. 2000. Denmark Vesey: The Buried Story of America's Largest Slave Rebellion and the Man Who Led It. Location: Vintage Books.

Robinson, Cedric J. 2005. Black Marxism: The Making of the Black Radical Tradition. Chapel Hill: University of North Carolina Press.

Roediger, David. 1991. The Wages of Whiteness. New York: Verso Books.

Roediger, David. 1994. Towards the Abolition of Whiteness. New York: Verso Books.

Sánchez, George J. 1993. Becoming Mexican American: Ethnicity, Culture, and Identity in Chicano Los Angeles, 1900-45. New York: Oxford University Press.

Siddle Walker, Vanessa. 2000. Their Highest Potential: An African American School Community in the Segregated South. Chapel Hill: University of North Carolina Press.

Smith, L. T. 2021. Decolonizing Methodologies: Research and Indigenous Peoples, 3rd ed. London: Zed Books by Bloomsbury Publishing.

Span, Christopher M. 2010. From Cottonfield to Schoolhouse: African American Education in Mississippi, 1862-1875. Chapel Hill: University of North Carolina Press.

Standing Bear, Luther. 2006. My People the Sioux. Lincoln: Bison Books. First Published 1928. 
Tachine, Amanda R. (Diné), and Eve L. Ewing. 2021. Cultivating Black \& Native Futures in Education. Virtual Conference. Available online: http: / / image.reply.asu.edu/lib / fe3a11717d64047c751270/m/2/f725a34d-572a-463e-8edf-926c400f8379.pdf (accessed on 18 October 2021).

Tamura, Eileen. 1994. Americanization, Acculturation, and Ethnic Identity: The Nisei Generation in Hawaii. Urbana: Univeristy of Illinois Press.

Tillman, Linda C. 2004. (Un)intended consequences? The impact of the Brown v. Board of Education decision on the employment status of Black educators. Education and Urban Society 36: 280-303. [CrossRef]

Treuer, David. 2019. The Heartbeat of Wounded Knee: Native America from 1890 to the Present. New York: Riverhead Books.

Trouillot, Michel-Rolph. 1995. Silencing the Past: Power and the Production of History. Boston: Beacon Press.

Tuck, E., and C. Ree. 2013. A glossary of haunting. In Handbook of Autoethnography. Edited by Stacy Holman Jones, Tony E. Adams and Carolyn Ellis. Walnut Creek: Left Coast Press, pp. 639-58.

Tuck, Eve, and K. Wayne Yang. 2012. Decolonization is not a metaphor. Decolonization: Indigeneity, Education E Society 1: 1-40.

Urban, Wayne J., Jennings L. Wagoner Jr., and Milton Gaither. 2019. American Education: A History. New York: Routledge.

Villegas, Malia, Sabina Rak Neugebauer, and Kerry R. Venegas, eds. 2008. Indigenous Knowledge and Education: Sites of Struggle, Strength and Survivance. Cambridge: Harvard Educational Review.

Wall Kimmerer, R. 2020. Braiding Sweetgrass: Indigenous Wisdom, Scientific Knowledge and the Teachings of Plants. New York: Penguin Books Limited.

Winant, H. 1997. Behind blue eyes. In Off White. Edited by Michelle Fine, Lois Weis, Linda Powell Pruitt and April Burns. New York: Routledge, pp. 40-53.

Woodruff, J. 2021. Why Americans Are So Divided over Teaching Critical Race Theory. PBS News Hour, June 24. Available online: https:/ / www.pbs.org/newshour/show/why-americans-are-so-divided-over-teaching-critical-race-theory (accessed on 15 July 2021).

Woodson, Carter G. 2013. The Mis-Education of the Negro. New York: Start Publishing LLC. First published 1933.

Wynter, Slyvia. 2003. Unsettling the coloniality of being/power/truth/freedom: Towards the human, after man, its overrepresentationAn argument. The New Centennial Review 3: 257-337. [CrossRef]

Yoon, Irene H. 2019a. Hauntings of a Korean American woman researcher in the field. International Journal of Qualitative Studies in Education 32: 447-64. [CrossRef]

Yoon, Irene H. 2019b. Haunted trauma narratives of inclusion, race, and disability in a school community. Educational Studies 55: 420-35. [CrossRef]

Yosso, Tara J. 2005. Whose culture has capital? A critical race theory discussion of community cultural wealth. Race Ethnicity and Education 8: 69-91. [CrossRef]

Zembylas, Michalinos. 2013. Pedagogies of hauntology in history education: Learning to live with the ghosts of disappeared victims of war and dictatorship. Educational Theory 63: 69-86. [CrossRef] 